\title{
ONE ROOF SYSTEM LEMBAGA PERADILAN AGAMA DI BAWAH KEKUASAAN MAHKAMAH AGUNG
}

\author{
Erfaniah Zuhriah \\ Fakultas Syariah UIN Maliki Malang \\ Telepon: 0341559399 \\ Email:erfaniah@yahoo.com
}

\begin{abstract}
History of judiciary power in Indonesia judicial institutions is quite long and dilemmatic. The political situation in Indonesia has a major impact on the existence of judicial institutions. Independence of judiciary power is not met a demand for years. It is proved by the interventions of extra-judicial government institutions to judicial institutions. The Supreme Court, as Indonesia's top court, at first has supervised General Courts, Religious Courts, State l Administration Court and the Military Courts only in judicial technical. Meanwhile, for non-judicial technical matters, those judicial institutions have been supervised by each government departments respectively. But with the enactment of Act No. 35 Year 1999 on Amendment of Act No. 14 Year 1970, which was enhanced by Act No. 4 Year 2004 on Judiciary Power, cultivation of non-judicial technical in those judicial institutions, including Religious Court have been held by the Supreme Court.

Sejarah kekuasaan kehakiman lembaga-lembaga peradilan di Indonesia cukup panjang dan dilematik. Situasi politik yang bergolak di Indonesia, berpengaruh besar terhadap eksistensi lembaga-lembaga peradilan. Independensi kekuasaan kehakiman tidak terpenuhi selama bertahun-tahun. Terbukti dengan banyaknya intervensi lembaga pemerintah ekstra-yudisial terhadap lembaga peradilan.Mahkamah Agung, sebagai puncak peradilan di Indonesia, pada mulanya hanya membina Peradilan Umum, Peradilan Agama, Peradilan Tata Usaha Negara dan Peradilan Militer secara teknis yudisial saja. Untuk urusan teknis nonyudisial,pembinaan lembaga-lembaga peradilan tersebut dibawah naungan departemen pemerintahan masing-masing. Namun seiring diundangkannya Undang-Undang Nomor 35 Tahun 1999 tentang Perubahan Atas Undang-Undang Nomor 14 Tahun 1970, yang kemudian disempurnakan dengan Undang-Undang Nomor 4 Tahun 2004 tentang Kekuasaan Kehakiman, pembinaan teknis non-yudisial lembaga-lembaga peradilan, termasuk Pengadilan Agama dipegang oleh Mahkamah Agung.
\end{abstract}

Keywords: Sistem Satu Atap, Mahkamah Agung, Pengadilan Agama.

\section{Pendahuluan}

Indonesia adalah negara hukum (rechtstaats), bukan negara kekuasaan (machstaats). Pemerintahannya didasarkan atas sistem konstitusi dan tidak bersifat absolutis- $\mathrm{me}^{1}$. Oleh sebab itu, setiap penyelenggaraan negara dan pemerintahannya harus didasarkan pada peraturan perundang-undangan.

1 C.S.T Kansil, Pengantar Hukum Indonesia Jilid II (Jakarta : Balai Pustaka, 2003), 21. 
Sejalan dengan ketentuan tersebut, maka salah satu prinsip negara hukum adalah adanya jaminan penyelenggaraan kekuasaan kehakiman yang merdeka sebagai instrumen netral menyelesaikan setiap perselisihan baik antar warga maupun antara warga dan penguasa $^{2}$. Kekuasaan kehakiman yang merdeka (an independent judicary) merupakan ideologi universal masa kini, maupun masa datang. Kekuasaan kehakiman yang merdeka juga merupakan ideologi trias politica atau state under rule of law yang dikenal dengan semboyan supremasi hukum (the law is supreme $)^{3}$. Untuk tercapainya tujuan-tujuan tersebut, maka diperlukan lembaga kehakiman untuk mewadahi seluruh kebutuhan dan kepentingan masyarakat.

Telah disebutkan dalam pasal 24 UUD 1945 ayat (1) sebelum amandemen bahwa "Kekuasaan Kehakiman dilakukan oleh sebuah Mahkamah Agung dan lain-lain badan kehakiman menurut Undang-Undang,". Penjelasan dari pasal 24 tersebut adalah "Kekuasaan kehakiman ialah kekuasaan yang merdeka, artinya terlepas dari pengaruh kekuasaan pemerintah. Berhubung dengan itu, harus diadakan jaminan dalam undang-undang tentang kedudukan hakim, "4 Ini artinya, kekuasaan kehakiman telah diakui dan diterima sejak negara merdeka sebagai salah satu sendi penyelenggaraan Indonesia.

Kemerdekaan kekuasaan kehakiman bisa dipahami dalam konteks kemerdekaan para hakim dalam menjalankan tugasnya. Namun, pada awal pemikiran elit politik dan pakar hukum, kedudukan para hakim yang merdeka itu tidak mutlak harus diwujudkan dalam bentuk pelembagaan yang tersendiri. Jalan pikiran demikian inilah yang berlaku selama bertahun-tahun. Sehingga, tidak pernah terbayangkan jika kekuasaan Mahkamah Agung dapat dikembangkan dalam satu atap kekua-

2 Bagir Manan, Kekuasaan Kehakiman Indonesia dalam UU No.4 Tahun 2004 (Yogyakarta: FH UII Press), 31.

${ }^{3}$ Yahya Harahap, Kekuasaan MA, Pemeriksaan Kasasi, dan Peninjauan Kembali Perkara Perdata (Jakarta: Sinar Grafika Offset, 1993), 4.

4 Undang-Undang Dasar 1945, Surabaya: Pustaka Agung, 2003. saan kehakiman yang mandiri secara institusional.

Ketidakmandirian lembaga kekuasaan kehakiman terjadi sejak Indonesia merdeka sampai berakhirnya era Orde Baru, Hal ini menunjukkan, bahwa proses peradilan di lingkungan lembaga-lembaga pengadilan di seluruh tanah air seringkali dipengaruhi oleh kekuasaan pemerintah. Akibatnya, kekuasaan kehakiman kita bukan saja tidak merdeka secara institusional administratif, tetapi juga secara fungsional-prosesual dalam proses penyelesaian perkara keadilan.

Perjalanan pengundangan tentang kekuasaan kehakiman pun melalui tahapan-tahapan yang panjang. Undang-undang yang mengatur mekanisme dan sistem peradilan itu dimulai dari lahirnya Undang-Undang Nomor 19 tahun 1948 tentang Susunan dan Kekuasaan Badan-badan Kehakiman dan Kejaksaan, Undang-Undang Nomor 19 Tahun 1964 Ketentuan Pokok Kekuasaan Kehakiman, Undang-Undang Nomor 14 Tahun 1970 tentang Ketentuan-ketentuan Pokok Kekuasaan Kehakiman, yang kemudian diubah dengan Undang-Undang Nomor 35 Tahun 1999 tentang Perubahan Atas Undang-Undang Tahun 1970 tentang Ketentuan-Ketentuan Pokok Kekuasaan Kehakiman, dan Undang-Undang Nomor 4 Tahun 2004 Tentang Kekuasaan Kehakiman.

Pada zaman Orde Lama, Presiden memiliki peranan cukup kuat dalam pelaksanaan kekuasaan kehakiman. Sedang pada masa Orde Baru, sekalipun mulai ada pembenahan sistem pemerintahan, termasuk di bidang peradilan, tetap saja ada kerancuan sistem. Intervensi lembaga eksekutif masih dilibatkan dalam urusan pembinaan lembaga peradilan. Sehingga lembaga peradilan belum juga mendapat kemerdekaan sebagaimana mestinya.

Namun, kondisi itu berubah sejak era reformasi. Tuntutan pembenahan sistem kenegaraan diusung dan diupayakan untuk segera dilakukan dan diwujudkan. Tuntutan reformasi yang mendasar terhadap sistem peradilan adalah menyangkut penataan kelembagaannya (institutional reform), mekanisme aturan yang bersifat instrumental (procedural 
reform), serta personalitas dan budaya kerja aparat peradilan serta perilaku hukum masyarakat Indonesia sebagai keseluruhan (ethical dan bahkan cultural reform). Dalam pengertian kita tentang sistem peradilan itu sendiri juga tercakup peranan dan fungsi kepolisian, kejaksaan, kepenasehatan, kehakiman, kepaniteraan, dan bahkan lembaga pemasyarakatan dalam satu kesatuan jaringan sistemik. Idealnya, perbaikan sistem peradilan tidak bisa hanya dengan tambal sulam, tetapi haruslah menyeluruh menyangkut semua aspek dan unsur sistem peradilan itu.

Ketentuan tersebutlah yang kemudian memunculkan gagasan untuk menyatuatapkan lembaga peradilan Indonesia. Selain sebagai bentuk kesadaran bahwa hukum adalah pilar utama penegak demokrasi yang penanganannya harus murni dan bebas dari intervensi manapun, pertanggungjawaban pemerintah, khususnya aparat hukum, juga merupakan kewajiban yang harus dilakukan. Melalui Sistem Satu Atap (One Roof System), Penegakan hukum yang dipercayakan pada Mahkamah Agung dan empat lembaga peradilan di bawahnya diharapkan bisa memberikan pelayanan publik terbaik di bidang hukum.

Pengadilan Agama, adalah pelaksana kekuasaan kehakiman di bawah Mahkamah Agung yang menjadi salah satu unsur pembenahan lembaga peradilan di Indonesia. Pertumbuhan dan perkembangannya berhubungan secara timbal balik dengan pranata hukum dan pranata sosial lainnya ${ }^{5}$. Ia tumbuh berkembang sejalan dengan perkembangan politik, yang berbasis pada struktur sosial dan pada budaya di dalam sistem masyarakat Bangsa Indonesia. Sejak awal pembentukannya, Pengadilan Agama selalu mengalami eksistensi yang dilematik. Pada zaman kolonial, melalui legitimasi yuridis Pemerintahan Belanda -berdasarkan Staatsblad No. 152Pengadilan Agama diperlakukan diskriminatif. Bentuk perlakuan diskriminatif yang dimaksud adalah membiarkan Pengadilan Agama tetap eksis, namun kewenangan dan kemajuannya tetap dikontrol ketat Belanda.

5 Jaih Mubarok (ed), Peradilan Agama di Indonesia (Bandung : Pustaka Bani Quraisy, 2004), 3.
Teori yang mengatur ini adalah receptie in complexu yang dikeluarkan oleh L. W. C. Van Den Berg (Ambiguitas posisi Pengadilan Agama juga terjadi setelah kemudian dikeluarkannya teori receptie oleh Snouck Horgronye. Dalam teori teori receptie disebutkan bahwa hukum Islam kerap mengalami tarik ulur dengan Hukum Adat yang dianggap sebagai hukum sebenarnya masyarakat Indonesia. Hukum Islam hanya dianggap sebagai hukum baru yang masuknya memberikan pengaruh sedikit terhadap hukum adat.

Ketika Indonesia merdeka, Pengadilan Agama belum bisa maju sebab diberlakukannya Peradilan Adat dan Peradilan Swapraja (sesuai dengan UU Darurat Nomor 1 Tahun 1951). Titelatur yang tak seragam, dasar hukum yang pluralistik, kewenangan waris yang semu, serta tidak adanya kewenangan eksekusi, membuat posisi Pengadilan Agama semakin kabur. Perubahan positif baru mulai terjadi ketika diundangkannya UndangUndang Perkawinan Nomor 1 Tahun 1974. Melalui Undang-Undang ini, kewenangan Pengadilan Agama bertambah, walau masih bergantung banyak pada Pengadilan Negeri.

Eksistensi Pengadilan Agama diperjelas dengan diaturnya hubungan fungsional antara Pengadilan Agama dengan Mahkamah Agung dalam PERMA No. 1 Tahun 1977 pada tanggal 26 November yang menyatakan bahwa acara kasasi untuk perkara perdata di lingkungan peradilan umum diberlakukan pula bagi peradilan agama. Dengan diterbitkannya PERMA-RI tersebut maka permohonan kasasi terhadap putusan yang berasal dari lingkungan peradilan agama telah memiliki dasar hukum. Dengan demikian, berakhirlah era dimana permohonan kasasi pernah diajukan di Direktorat Peradilan Agama Departemen Agama yang notabene adalah lembaga eksekutif ${ }^{6}$.

Posisi Pengadilan Agama semakin mendapat tempat dengan dikukuhkannya Undang-Undang Nomor 7 Tahun 1989 tentang Pengadilan Agama tanggal 29

${ }^{6}$ Husnaini, "Visi dan Misi Peradilan Agama Pasca Satu Atap", Mimbar Hukum Vol 66 (2005), hal 12. 
Desember 1989. Undang-Undang ini menjadikan Pengadilan Agama sebagai lembaga peradilan yang penting peranannya, karena hak opsi dalam perkara waris diakui serta Pengadilan Agama bisa mengeksekusi putusannya sendiri. Sayangnya, dalam undangundang ini ternyata masih ada campur tangan lembaga eksekutif-Departemen Agamadalam urusan peradilan. Dalam soal teknis yudusial, Pengadilan Agama memang berada di bawah pembinaan Mahkamah Agung. Namun, dalam urusan teknis non-yudisial, Pengadilan Agama berada dalam pembinaan Menteri Agama.

Dari perjalanan sejarah pengadilan Agama di atas, terlihat bahwa kekuasaan kehakiman sempat kehilangan identitasnya. Padahal idealnya, kekuasaan tiga lembaga negara, yakni eksekutif, legis latif, dan yudikatif, haruslah dipisahkan ${ }^{7}$. Sehingga, tidak seharusnya Pengadilan Agama diposisikan di bawah Departemen Agama yang notabene bukan lembaga yudisial. Sebenarnya, realitas peradilan semacam itu bukan hanya menimpa Pengadilan Agama, namun juga lembaga peradilan umum, militer dan tata usaha negara juga. Lembaga-lembga peradilan tersebut pembinaan non-yudisialnya di bawah kendali departemen pemerintahan masingmasing.

\section{Latar Belakang Ditetapkannya Sistem Satu Atap (One Roof System)}

Kesadaran terhadap idealitas sebuah negara hukum baru terbukti dengan diundangkannya Undang-Undang Nomor 3 Tahun 1999 tentang Perubahan Atas UndangUndang Nomor 14 Tahun 1970 Tentang Ketentuan-Ketentuan Pokok Kekuasaan Kehakiman. Sebab, undang-undang ini memuat ide penyatuatapan yang sebenarnya telah lama bergulir. Penyatuatapan di sini adalah kesatuan pembinaan baik di bidang penanganan perkara maupun organisasi, admnistrasi, dan keuangan. Tapi, karena situasi politik masih sangat labil, maka implementasi undang-undang ini belum

7 Konsep pemisahan kekuasaan tiga lembaga negara, yaitu legislatif, eksekutif, dan yudikatif, dicetuskan oleh Montesquieu. mencapai target yang diharapkan. Pembinaan non-yudisial Pengadilan Agama tidak serta merta dialihkan ke Mahkamah Agung, sekalipun penyatuatapan sudah ditetapkan sebagai sistem baru. Departemen Agama masih saja terlibat dalam urusan non-yudisial Pengadilan Agama sampai tahun 2004.

Undang-Undang Nomor 35 Tahun 1999 ini kemudian disempurnakan oleh UndangUndang Nomor 4 tahun 2004 Tentang Kekuasaan Kehakiman. Kelahiran UndangUndang ini adalah merupakan tuntutan pasca amandemen UUD 1945. Selain mengatur independensi lembaga peradilan di Indonesia, Undang-undang ini juga mengatur ketentuan pelaksana kekuasaan kehakiman baru, yaitu Mahkamah Konstitusi.

Setelah pengundangan Undang-Undang Nomor 4 Tahun 2004 inilah, maka seluruh pembinaan organisasi, administrasi, dan finansial (OAF) Pengadilan Negeri, Pengadilan Agama, Pengadilan Tata Usaha Negara, dan Pengadilan Militer harus segera dialihkan ke Mahkamah Agung. Ketentuanketentuan tersebut terlaksana setelah diterbitkannya Keppres RI Nomor 21 Tahun 2004 yang juga mengatur pengalihan OAF keempat lingkungan peradilan ke Mahkamah Agung. Mahkamah Agung, sebagai puncak peradilan pada akhirnya membina secara penuh empat lembaga peradilan di bawah naungannya.Pemberlakukan Sistem Satu Atap (one roof system) diharapkan mampu memajukan kinerja dan mewujudkan citra positif peradilan di Indonesia, termasuk Pengadilan Agama ${ }^{8}$. Harapan itu dimuluskan dengan mengatur mekanisme Sistem Satu Atap (One Roof System) keempat lembaga di bawah kekuasaan Mahkamah Agung melalui undang-undang yang sesuai dengan kekhususan lingkungan peradilan masingmasing. Saat ini, pengaturan mengenai organisasi, administrasi, dan finansial lembaga Peradilan Agama ke satu atap di bawah kekuasaan Mahkamah Agung semakin kokoh dengan keluarnya UU Nomor 3 Tahun 2006 Perubahan Atas Undang-Undang

8 M. Fauzan, Pokok-Pokok Hukum Acara Perdata dan Mahkamah Syari'ah di Indonesia (Cet III. Jakarta: Kencana, 2007), 3 
Nomor 7 Tahun 1989 Tentang Peradilan Agama 9 .

Dari sini, peneliti merasa perlu mencermati dan mengkaji lebih pemberlakuan Sistem Satu Atap (One roof system) yang mulai ditetapkan sejak diund angkannya Undang-Undang Nomor 35 Tahun 1999 dan disempurnakan oleh Undang-Undang Nomor 4 Tahun 2004. Kajian ini selain mencakup kajian historis, juga mencakup orientasi serta implikasi diberlakukannya Sistem Satu Atap (One roof system), khususnya di lingkungan Pengadilan Agama. Sebab, kondisi organisasi, administrasi, serta finansial (OAF) Pengadilan Agama menurut Undang-Undang Nomor 7 Tahun 1989 (Sebelum diberlakukannya Sistem Satu Atap) dengan kondisi organisasi, administrasi, serta finansial (OAF) Pengadilan Agama menurut Undang-Undang Nomor 3 Tahun 2006 (pasca diberlakukannya Sistem Satu Atap) banyak mengalami perubahan yang. Perbedaan inilah yang kemudian menarik untuk dicermati dan diidentifikasi lebih lanjut.

Pemberlakuan Sistem Satu Atap (One roof system) tentu memiliki konsekuensikonsekuensi. Mahkamah Agung, juga empat lingkungan peradilan yang di bawahinya, jelas mengalami perubahan yang tak mainmain. Segala urusan yang berkenaan dengan organisasi, administrasi, dan keuangan empat lembaga peradilan harus di bawah pembinaan Mahkamah Agung. Sekalipun dalam pengelolaannya empat lingkungan peradilan tersebut diberi wewenang, namun peningkatan kualitas aparat peradilan, kemajuan teknik administrasi, dan

\footnotetext{
${ }^{9}$ Pengaturan mengenai satu atap terdapat pada pasal I angka 4 mengenai perubahan bunyi pasal 5 ayat (1) UU Nomor 7 Tahun 1989 yang berbunyi: "Pembinaan teknis peradilan, organisasi, administrasi, dan finansial pengadilan dilakukan oleh Mahkamah Agung,". Sedangkan pada pasal 1 angka 6 juga terdapat penyesuaian terhadap bunyi pasal 12 ayat (1) UU Peradilan Agama tersebut sehingga berbunyi: "Pembinaan dan pengawasan umum terhadap hakim dilakukan oleh Ketua Mahkamah Agung" (Lihat : Sulaikin Lub is dkk, Hukum Acara Perdata Peradilan Agama di Indonesia (Cet. II; Jakarta: Kencana, 2006), 39)
}

pertanggungjawaban alokasi anggaran tetap di bawah kendali Mahkamah Agung. Dalam prakteknya, kendala-kendala tersebut acap kali muncul dan menuai banyak kritik.

Ditinjau dari struktur organisasinya, Pengadilan Agama ditangani khusus oleh Ditjen Badilag Mahkamah Agung. Sejak diberlakukannya Sistem Satu Atap (One Roof System), maka segala urusan organisasi, administrasi, dan finansial Pengadilan Agama dibebankan pada Ditjen Badilag. Kondisi ini belum pernah terjadi di lingkungan Pengadilann Agama. Namun, dalam prakteknya, ada saja kendala dan kekurangan yang terjadi pasca diberlakukannya Sistem Satu Atap (One roof system). Kendalakendala ini terjadi karena belum matangnya kesiapan di tubuh Mahkamah Agung dan Pengadilan Agama itu sendiri.

Berkenaan dengan kronologi kasus di atas, maka peneliti merasa perlu untuk melakukan penelitian mengenai Sistem Satu Atap (One roof system). Selain perjalanan sejarahnya yang panjang dan menarik, pemenuhan tuntutan dalam Sistem Satu Atap (One roof system) oleh lembaga peradilan, khususnya Pengadilan Agama, sangat penting untuk dikaji. Hal ini nanti berakibat pada implikasi diberlakukannya Sistem Satu Atap (One roof system), apakah benar-benar seperti yang diharapkan, atau sebaliknya, memunculkan ironi baru dalam lembaga peradilan. Bila memang dampaknya positif, maka program-program apa saja yang menyebabkan dampak positif tersebut. Sebaliknya, bila berdampak negatif, program apa yang merupakan melemahkan sistem tersebut.

Bagi Pengadilan Agama, yang memiliki perjalan sejarah yang panjang dan dilematik, Sistem Satu Atap (One roof system) tentu merupakan sebuah tantangan baru. Butuh kerja keras dan kesungguhan untuk bisa mencapai hasil yang menjadi harapan Sistem Satu Atap (One Roof System).

\section{Fungsi Kekuasaan Kehakiman MA Pasca Satu Atap}

Mahkamah Agung (MA) merupakan puncak kekuasaan kehakiman di Indonesia. 
Kekuasaan kehakiman tersebut, sesuai dengan Penjelasan Pasal 24 dan 25 UUD 1945 merupakan kekuasaan yang merdeka, terlepas dari pengaruh kekuasaan pemerintah. Kata-kata merdeka dan terlepas dari pengaruh kekuasaan pemerintah itu mengandung pengertian yang bersifat fungsional sekaligus institusional. Tapi, ada saja yang hanya membatasi secara fungional saja, yaitu bahwa kekuasaan pemerintah tidak boleh melakukan intervensi yang bersifat atau yang patut dapat diduga akan mempengaruhi jalannya proses pengambilan keputusan dalam penyelesaian perkara yang dihadapi oleh hakim ${ }^{10}$. Terlepas dari persoalan kemerdekaan atau batasan pengaruh, fungsi kekuasaan Mahkamah Agung (MA) adalah tetap sebagai pembina kekuasaan kehakiman yang mandiri dan terpadu di seluruh lingkungan peradilan, baik secara yudisial maupun non-yudisial.

Tugas dan wewenang Mahkamah Agung pasca Satu Atap adalah memeriksa dan memutus permohonan kasasi, sengketa kewenangan mengadili, permohonan peninjauan kembali putusan yang telah memperoleh kekuatan hukum yang tetap dan permohonan pengujian peraturan perundangundangan. Di samping itu, dapat pula diatur mengenai kewenangan Mahkamah agung (MA) untuk memberikan pendapat hukum atas permintaan Presiden ataupun lembaga tinggi negara lainnya ${ }^{11}$.

Mahkamah Agung juga dapat memberikan pertimbangan hukum atas permintaan Presiden ataupun lembaga tinggi negara lainnya. Hal ini dianggap perlu, agar

10 Jimly Asshidiqie, Format Kelembagaan Negara dan Pergeseran kekuasaan Dalam UUD 1945, Yogyakarta: FH UII Press, Cet II, 2005), 213

${ }^{11}$ Ketentuan ini diatur dalam Pasal 28 ayat (1) Undang-Undang Nomor 5 Tahun 2004 Tentang Perubahan Atas Undang-Undang Nomor 14 Tahun 1985 Tentang Mahkamah Agung, Lembar Negara Republik Indonesia Nomor 9 Tahun 2004 (Jakarta: Proyek Penyusunan Rancangan UU Direktorat Pembinaan Pengadilan Agama, 2004), 49. Bunyi Pasal 28 tersebut adalah: (1) Mahkamah Agung bertugas dan berwenang memeriksa dan memutus: a. Permohonan kasasi, b. Sengketa tentang kewenangan mengadili, $c$. Permohonan peninjauan kembali putusan Pengadilan yang telah memperoleh kekuatan hukum tetap.
Mahkamah Agung benar-benar dapat berfungsi sebagai rumah keadilan bagi siapa saja dan lembaga mana saja yang memerlukan pendapat hukum mengenai sesuatu masalah yang dihadapi.

Selain itu, Mahkamah Agung diberi wewenang menguji semua bentuk dan tingkatan peraturan perundang-undangan di bawah UUD 1945. Mahkamah Agung berwenang untuk menilai, apakah suatu produk peraturan perundang-undangan bertentangan atau tidak bertentangan dengan UUD 1945 sebagai hukum dasar tertinggi. Karena UUD 1945 sekarang menganut prinsip pemisahan kekuasaan, meskipun masih juga menganut sistem pembagian kekuasaan karena masih dipertahankannya lembaga MPR, maka alasan untuk menolak kewenangan Mahkamah Agung melakukan pengujian UU terhadap UUD tidak ada lagi.

\section{Pembinaan MA Terhadap Le mbaga PA}

Dari paparan tugas dan wewenang Mahkamah Agung di atas, kolerasinya dengan Pengadilan Agama adalah bahwa untuk menjadi bagian dari lembaga peradilan yang sejajar dengan lembaga peradilan lain, Pengadilan Agama telah mengalami sejarah yang panjang. Selama ini, perjuangan berat untuk mengajegkan eksistensi pengadilan Agama sebagai salah satu pelaksana kekuasaan kehakiman tidalkah mudah. Dengan diberlakukannya Undang-Undang Nomor 4 Tahun 2004, Pengadilan Agama tidak lagi mendapatkan diskriminasi. Sebab, secara teknis yuridis maupun organisasi, administrasi, dan finansial, Pengadilan Agama sudah di bawah pembinaan Mahkamah Agung (MA) layaknya tiga lembaga peradilan lainnya.

Pengalihan pembinaan ini diatur dalam Keppres Nomor 21 Tahun 2004 Pasal 2 Ayat $(1)^{12}$ dan Ayat $(2)^{13}$ mengenai ketentuan

12 Bunyi Pasal tersebut adalah : organisasi, administrasi, dan keuangan pada Direktorat Jendral Badan Peradilan Umum Peradilan Tata Usaha Negara Departemen Kehakiman dan Hak Asasi Manusia, Pengadilan Tinggi, Pengadilan Tinggi Usaha Negara, Pengadilan Negeri, Pengadilan Tata Usaha Negara terhitung sejak tanggal 31 maret 2004 
pengalihan oraganisasi, administrasi, dan finansial Pengadilan Agama secara khusus. Dari ketetapan ini, kini semua pembinaan lembaga peradilan, termasuk Pengadilan Agama telah beralih ke Mahkamah Agung. Secara teknis, peradilan Agama tidak terkait lagi dengan Departemen Agama walau dalam catatan sejarah tetap terukir bahwa Peradilan Agama dilahirkan dari induknya, yaitu Departemen Agama ${ }^{14}$. Dari situlah kemudian diputuskan bahwa pembinaan Pengadilan Agama tetap dilakukan dengan memperhatikan saran dan pendapat Menteri Agama dan Majelis Ulama Indonesia.

Pembinaan profesionalisme dan pengembangan kesejahteraan hakim serta penataan kelembagaan Pengadilan Agama perlu terus ditingkatkan dan dimantapkan sesuai dengan perkembangan. Semua hak dan kewajiban hakim serta badan-badan Pengadilan Agama di seluruh Indonesia dikembangkan sama dengan apa yang dikembangkan kepada lembaga pengadilan lainnya.

\section{Hubungan Struktural Mahkamah Agung dengan Lembaga Peradilan Agama}

Pasca diberlakukannya Sistem Satu Atap (One Roof System), maka di lingkungan Mahkamah Agung mengalami banyak perubahan. Secara struktur organisasi, di Mahkamah Agung di samping ada Wakil Ketua Bidang Yudisial, diangkat pula Wakil Ketua Bidang Non Yustisial. Selain itu, diangkat pula Ketua Muda Mahkamah Agung Bidang Pembinaan dan sebagai ujung tombak pembinaan terhadap Mahkamah Agung serta badan-badan Peradilan di bawahnya bersama-

dialihkan dari Departemen Kehakiman dan Hak Asasi Manusia ke Mahkamah Agung.

13 Bunyi Pasal tersebut adalah : organisasi, administrasi, dan keuangan pada Direktorat Jendral Badan Peradilan Umum Peradilan Tata Usaha Negara Departemen Kehakiman dan Hak Asasi Manusia, Pengadilan Tinggi, Pengadilan Tinggi Usaha Negara, Pengadilan Negeri, Pengadilan Tata Usaha Negara terhitung sejak tanggal 31 maret 2004 dialihkan dari Departemen Kehakiman dan Hak Asasi Manusia ke Mahkamah Agung.

14 Erfaniah Zuhriah, Peradilan Agama di Indonesia dalam Rentang Sejarah dan Pasang Surut (Malang: UIN Press,2008), 153. sama Sekretaris Mahkamah Agung. Untuk keperluan pengawasan di angkat pula Ketua Muda Mahkamah Agung Bidang Pengawasan. Kemudian, Direktoral Pembinaan Badan Peradilan Agama (yang semula berada di Departemen Agama dipindahkan ke Mahkamah Agung) menjadi Direktorat Jendral Badan Peradilan Agama, sehingga kewenangan menjadi semakin luas.

Bila dilihat dari struktur, ada dua jalur yang menghubungkan peradilan agama dengan Mahkamah Agung, yaitu Wakil Ketua Bidang Yudisial dan dari Sekretaris Mahkamah Agung. Hubungan dari jalur Wakil Ketua Bidang Yudisial bisa dilihat dari struktur Mahkamah Agung sebagai berikut : 


\section{Gambar 7 \\ Bagan Posisi Urusan Peradilan Agama dalam Struktur Mahkamah Agung}

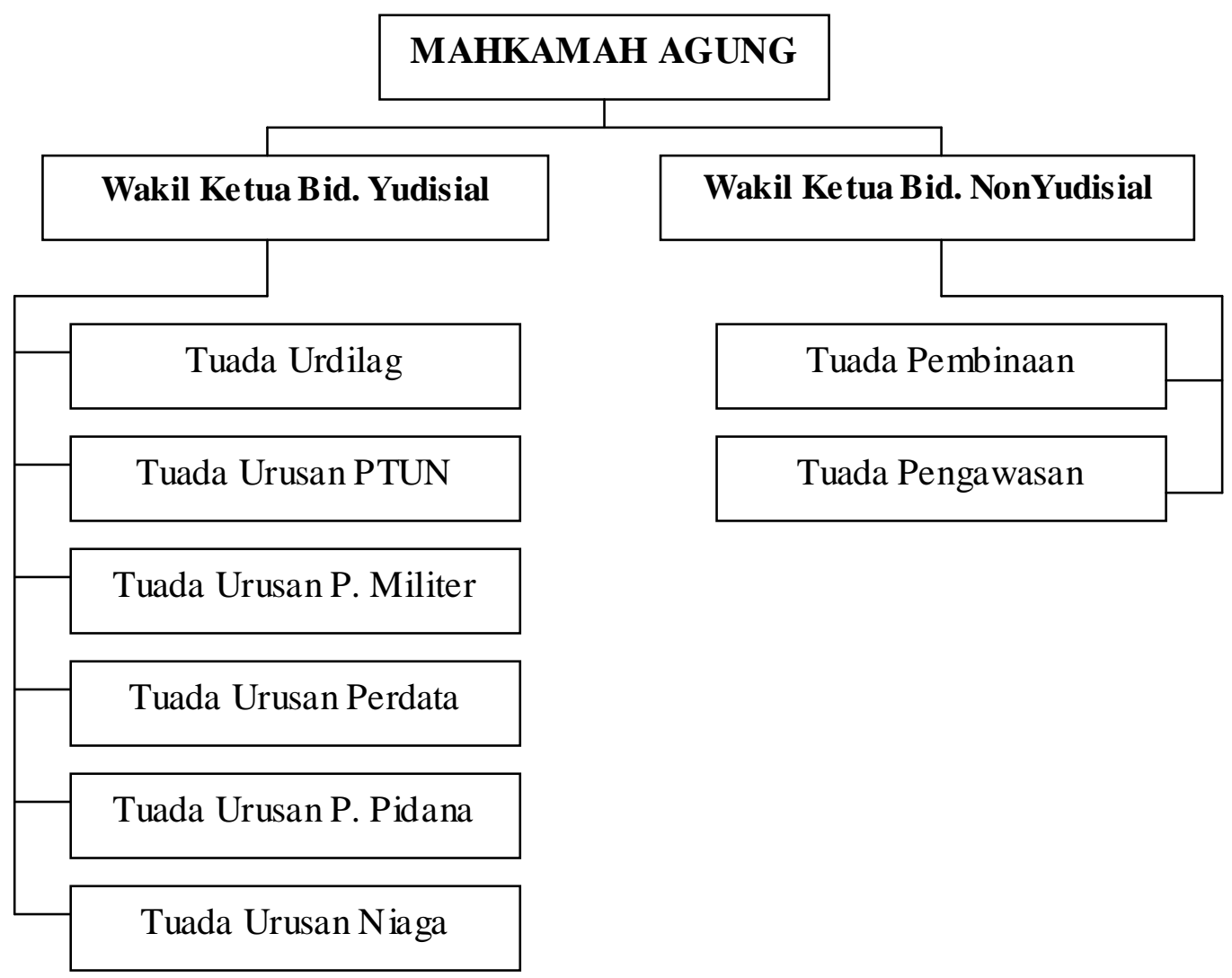

Salah satu unsur pimpinan yang berada di bawah wakil ketua bidang yudisial adalah Ketua Muda Urusan Peradilan Agama. Tugas dan fungsinya adalah melakukan pembinaan teknis yustisial perkara di lingkungan Peradilan agama.

Selain Wakil Ketua, dalam struktur MA terdapat Sekretaris Mahkamah Agung sebagai pimpinan sekretariat. Pada Sekretariat Mahkamah Agung ini, dibentuk beberapa Direktorat Jendral dan Badan yang dipimpin oleh beberapa Direktur Jendral dan Kepala Badan. Ketentuan mengenai susunan organi-

sasi, tugas, tanggung jawab, dan tata kerja sekretariat serta badan pada MA ditetapkan dengan keputusan Presiden. Menurut Peraturan Presiden Nomor 13 Tahun 2005 tanggal tentang Sekretariat Mahkamah Agung; Sekretariat Mahkamah Agung mempunyai tugas membantu Ketua Mahkamah Agung dalam menyelenggarakan koordinasi dan pembinaan dukungan teknis, administrasi, organisasi dan finansial kepada seluruh unsur di lingkungan Mahkamah Agung dan pengadilan di semua lingkungan peradilan. Adapun strukturnya adalah sebagai berikut: 
Gambar 8

Bagan Struktur Sekretariat Mahkamah Agung RI

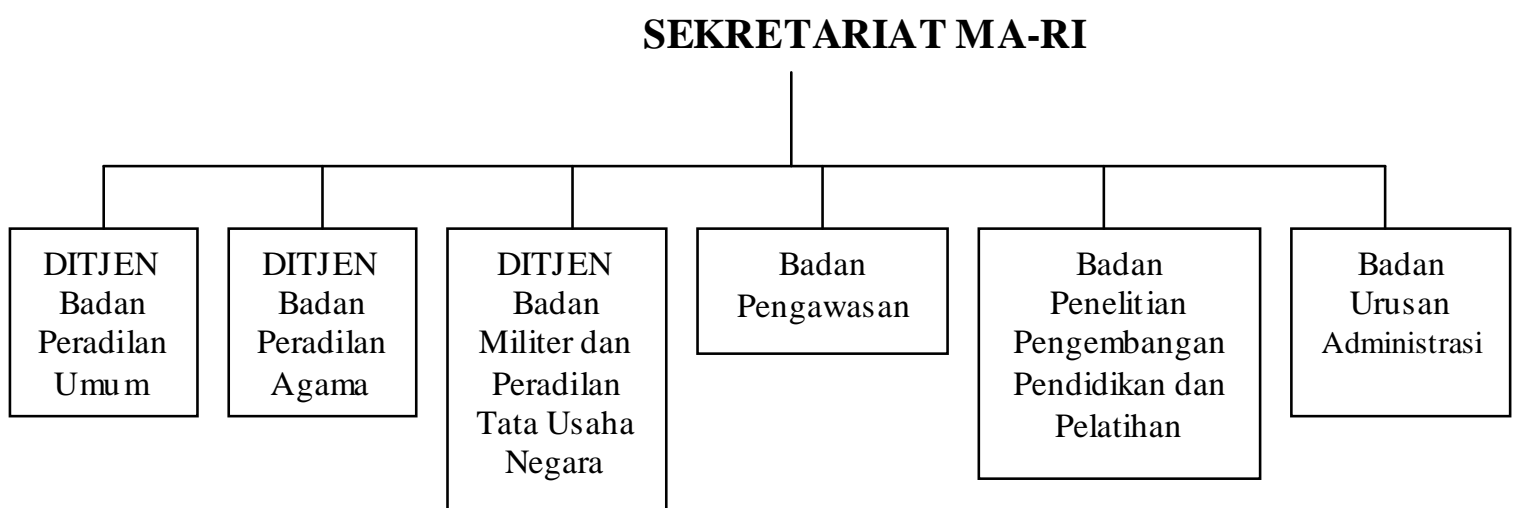

Direktorat Jendral Badan Peradilan Agama mempunyai tugas membantu sekretaris Mahkamah Agung dalam merumuskan dan melaksanakan kebijakan dan standarisasi teknis di bidang pembinaan tenaga teknis, pembinaan administrasi peradilan, pranata dan tata laksana perkara dari lingkungan peradilan agama pada Mahkamah Agung dan pengadilan di lingkungan peradilan agama. Jadi, secara operasional, Dirjen Badilag hanya mengurusi persoalan administrasi, baik kekuangan, perencanaan, perkantoran, kepegawaian, sampai pada administrasi perkara dan tidak menyangkut masalah perkara atau yustisialnya.

Sedangkan tugas pokok dan fungsi Dirjen Badilag yang diatur dalam Perpres Nomor 13 Tahun 2005 diimplementasikan dengan surat Sekretaris Mahkamah Agung RI Nomor: MA/SEK/07/SK/III/2006 tentang Organisasi dan Tata Kerja Sekretaris Mahkamah Agung Republik Indonesia ${ }^{15}$. Dalam keputusan tersebut, ditetapkan bahwa Dirjen Badan Peradilan Agama terdiri atas :

a) Sekretariat Direktorat Jendral Badan Peradilan Agama, b) Direktorat Pembinaan Tenaga Teknis Peradilan Agama, c) Direk torat Pembinaan Administrasi Peradilan Agama, dan d) Direktorat Pranata dan Tata Laksana Perkara Perdata Agama.

15 Aripin, Jaenal (2008) "Peradilan Agama dalam Bingkai Reformasi Hukum di Indonesia”. Jakarta: Prenada Media Group.hal 318
Secara struktural, susunan organisasi yang berada di bawah Dirjen Badan Peradilan Agama tersebut berada pada posisi Eselon II. Inilah pengembangan yang terjadi pada lingkungan peradilan agama yang semula hanya tingkat sirektorat sekarang berada pada posisi Dirjen, sehingga struktur dan pejabat yang mengisinya mengalami peningkatan eselon. Peningkatan eselon bisa dilihat dari gambar di bawah ini : 


\section{Gambar 9 \\ Bagan Struktur Direktorat Jendral Badan Peradilan Agama}

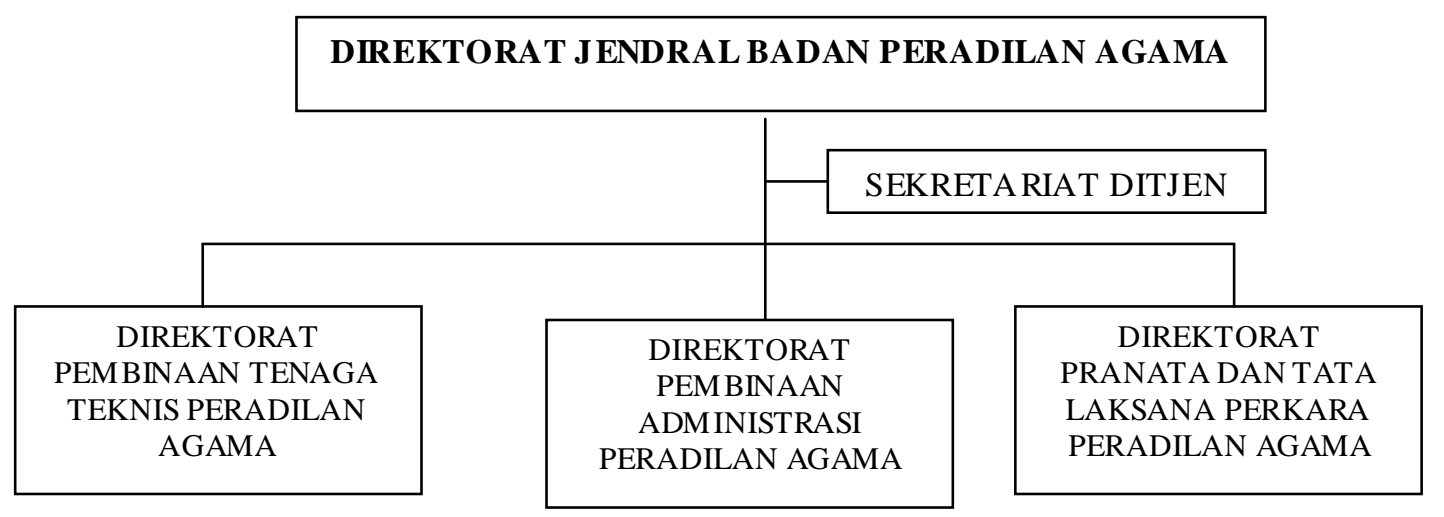

Keterangan gambar 9 :

1. Sekretariat Direktorat Jendral Badan Peradilan Agama mempunyai tugas memberikan dukungan teknis administrasi kepada semua unsur di lingkungan Dirjen Badilag yang menyangkut SDM, keuangan, perencanaan, kepegawaian, termasuk administrasi ta ta laksana perkara, dan sarana serta prasarana.

2. Direktorat Pembinaan Tenaga Teknis Peradilan Agama mempunyai tugas melaksanakan penyiapan bahan perumusan dan pelaksanaan kebijakan, perumusan standar, norma, kriteria, dan prosedur serta pemberian bimbingan teknis dan evaluasi di bidang pembinaan tenaga teknis peradilan agama.

3. Direktorat Pembinaan Administrasi mempunyai tugas melaksanakan penyiapan bahan perumusan dan pelaksanaan kebijakan, perumusan standar, norma, kriteria, dan prosedur serta pemberian bimbingan teknis dan evaluasi di bidang pembinaan administrasi peradilan agama.

4. Direktorat Pranata Dan Tata Laksana Perkara Peradilan Agama mempunyai tugas melaksanakan penyiapan bahan perumusan dan pelaksanaan kebijakan, di bidang pranata dan tata laksana perdata agama serta kesyari'ahan.

Setelah Sistem Satu Atap (One Roof System) diberlakukan, Mahkamah Agung tidak hanya mengurusi pembinaan para hakim saja, tetapi juga menangani organisasi, administrasi serta finansial Pengadilan Umum, Pengadilan Agama, Pengadilan Militer, dan Pengadilan Tata Usaha Negara. Urusan teknis yudisial dan kepegawaian korps hakim sepenuhnya menjadi tanggungjawab Mahkamah Agung. Ini akan mempermudah pengawasan terhadap para hakim. Sebab, selama selama ini, Sistem Dua Atap (Double Roof System) telah mempersulit pengawasan Mahakamah Agung.

Tindak lanjut dari sistem satu atap adalah lahirnya Undang-Undang baru yang mengatur secara khusus masing-masing lingkungan peradilan. Undang-Undang tersebut antara lain Undang-Undang Nomor 9 Tahun 2004 tentang Perubahan Atas UndangUndang Nomor 5 Tahun 1986 tentang Peradilan Tata Usaha Negara, UndangUndang Nomor 8 Tahun 2004 tentang Perubahan Atas Undang-Undang Nomor 2 Tahun 1986 tentang Peradilan Umum, Undang Nomor 3 Tahun 2006 tentang Perubahan Atas Undang-Undang Nomor 7 Tahun 1989 tentang Pengadilan Agama, dan Undang-Undang Nomor 31 Tahun 1997 Tentang Peradilan Militer 


\section{DAFTAR PUSTAKA}

Aripin, Jaenal (2008) "Peradilan Agama dalam Bingkai Reformasi Hukum di Indonesia". Jakarta: Prenada Media Group.

Asshidiqie, Jimly (2005) "Format Kelembagaan Negara dan Pergeseran kekuasaan Dalam UUD 1945". Yogyakarta: FH UII Press.

Harahap, Yahya (2008) "Kekuasaan Mahkamah Agung, Pemeriksaan Kasasi, dan Peninjauan Kembali Perkara Perdata". Jakarta: Sinar Grafika Offset.

Harahap, Yahya (2003) 'Kedudukan Kewenangan dan Acara Perdata Pengadilan Agama". Jakarta : Sinar Grafika.

Hasan Bisri, Cik (2003) 'Peradilan Agama di Indonesia”. Jakarta: PT. Raja Grafindo Persada.

Himpunan Peraturan Perundang-Undangan (1993). Jakarta : Mahkamah Agung Husnaini, dkk (2005) Mimbar Hukum Vol 66 Thn XVI Sepember-Oktober.

Husnaini dkk. (2005) Jurnal Mimbar Hukum, No.66 Thn XVI, September-Oktober.

Jaih Mubarok (ed), Peradilan Agama di Indonesia (Bandung : Pustaka Bani Quraisy, 2004)

Jimly Asshidiqie, Format Kelembagaan Negara dan Pergeseran kekuasaan Dalam UUD 1945, Yogyakarta: FH UII Press, Cet II, 2005.
Manan, Bagir (.......) "Kekuasaan Kehakiman Indonesia dalam UU No.4 Tahun 2004". Yogyakarta: FH UII Press.

Manan, Bagir (2004) "Sistem Peradilan Berwibawa". Jakarta: Mahkamah Agung RI.

Manan, Bagir (2004) "Sambutan Penutupan Ketua Mahkamah Agung Pada Rapat Kerja Nasional Tahun 2004”. Semarang : Mahkamah Agung.

M. Fauzan (2007) Pokok-Pokok Hukum Acara Perdata dan Mahkamah Syari'ah di Indonesia”. Cet III. Jakarta: Kencana.

Zuhriah, Erfaniah (2008) "Peradilan Agama di Indonesia dalam Rentang Sejarah dan Pasang Surut". Malang: UIN Press.

Undang-Undang Nomor 3 Tahun 2006 Lembar Negara 22 Tahun 2006 tentang Perubahan Atas Undang-Undang Nomor 7 Tahun 1989Tentang Peradilan Agama

Undang-Undang Nomor 5 Tahun 2004 Tentang Perubahan Atas UndangUndang Nomor 14 Tahun 1985 Tentang Mahkamah Agung Lembar Negara Nomor 9 Tahun 2004 (2004) Jakarta: Proyek Penyusunan Rancangan Undang-Undang Direktorat Pembinaan Pengadilan Agama.

www.tempointeraktif.com. "Repotnya Memboyong Perut", tulisan Ahmad Taufik, dkk (dimuat tanggal 25 Februari 2004) 